\title{
POLLEN OF SYZYGIUM (MYRTACEAE) FROM SE ASIA, ESPECIALLY THAILAND
}

\author{
J. PARNELL \\ Herbarium, School of Botany, Trinity College, Dublin, Ireland
}

\begin{abstract}
SUMMARY
Pollen of 57 species of Syzygium from SE Asia were surveyed by SEM. The grains are all \pm triangular in polar view, uniformly small (mean diameter $10.4 \mu \mathrm{m}$ ) with few surface sculpturing features. All species examined exhibit a distinct apocolpium and, usually, apocolpial field. The presence of an apocolpial field cannot be linked to any known taxonomic grouping within the genus. It does not appear possible to distinguish the species of Syzygium on the basis of features of the pollen visible under SEM, though section Jambosa tends to have larger pollen with a proportionally larger apocolpium than species not in that section. Estimates for the number of pollen grains per stamen in species with larger pollen grains ( \pm section Jambosa) are $5 \times$ as great as for other species in the genus. TEM preparations showed the pollen surface to bear small supratectal processes and to be covered with pollenkit. The foot layer is well developed and more or less of the same thickness as the tectum. The columellae are of variable width and the endexine c. $0.05 \mu \mathrm{m}$ thick. Various features of flower size are found to be positively correlated to pollen size. As large pollen grains are linked to large staminal numbers and large stamens (long filaments and large anthers) it is suggested that investigation of the breeding biology of section Jambosa is required.
\end{abstract}

Key words: Myrtaceae, Syzygium, breeding biology, pollen morphology.

\section{INTRODUCTION}

The Myrtaceae are a moderately sized, mostly southern hemisphere family containing between 132 and 150 genera and somewhere between 3,675 and 3,900 species (Schmid, 1980; Johnson et al., 1988; Kochummen, 1995; Lemmens, 1995; Mabberley, 1997). Despite its modest size the family is an extremely important component of the flora of the southern hemisphere. For example, tree species in the family dominate the forests of Australia and there are many taxa which form important components of the forests of Southeast Asia, South America and the islands of Oceania (Johnson \& Briggs, 1981). In addition, a number of species are of local or international economic importance for timber or as a forest product (e.g. Lemmens, 1995).

In many members of the Myrtaceae the stamens perform the dual functions of pollen production and dispersal and the function of pollinator attraction through the formation of brush-blossom inflorescences (Johnson \& Briggs, 1981). The widespread and species-rich genus Syzygium is a good example of this pollination syndrome.

Syzygium is often thought of as closely allied to Eugenia, though most current workers accept that the relationship is more distant than previously thought. Certainly, both are large genera: there are at least 3,000 binomials available in the latter and over 1,000 in the former (Parnell, 1999). Though these figures probably do not ac- 
curately reflect the balance in species numbers between the genera they are indicative of their scale, with possibly 600 species in Eugenia and 1,000 in Syzygium. Parnell (1999) has proposed that Syzygium be subdivided, with the recognition of a small, monophyletic section - section Jambosa - and another, larger, paraphyletic group. Jambosa includes Syzygium anacardiifolium (Craib) Chantar. \& J. Parn., S. aqueum (Burm.f.) Alston, S. diospyrifolium (Wall. ex Duthie) S.N. Mitra, S. formosum (Wall.) Masam., S.foxworthianum (Ridl.) Merr. \& L.M. Perry, S. jambos (L.) Alston in Trimen, S. lakshanakarae Chantar. \& J. Parn., S. malaccense (L.) Merr. \& L.M. Perry, S. megacarpum (Craib) Rathakr. \& N.C. Nair, S. papillosum (Duthie) Merr. \& L.M. Perry, S. pseudoformosum (King) Merr. \& L.M. Perry, S. pycnanthum Merr. \& L.M. Perry, S. samarangense (Blume) Merr. \& L.M. Perry, S. scortechinii (King) Chantar. \& J. Parn., and S. siamense (Craib) Chantar. \& J. Parn. Though his proposed division is based on a substantial sub-sample of Syzygium and is the product of phylogenetic and phenetic analyses of many morphological characters it is clear from his paper that there is a dearth of information on pollen morphology. This paper aims to plug that gap, at least in part.

\section{ANDROECIUM AND POLLEN}

It has been proposed that the ancestral form of the Myrtaceae flower had a prominent androecium (Johnson \& Briggs, 1984), somewhat similar to the brush-blossom type. Thus, a more 'traditional', non brush-blossom type of flower seems a derived state in the Myrtaceae. These traditional flower forms are mainly found in the Leptospermum and Chamelaucium informal taxonomic groups of Johnson \& Briggs (1984) and are located as sister, distal groups in their phylogram outlining relationships in the Myrtaceae. Therefore, it appears that floral characteristics directly reflect phylogeny.

Despite their potential importance as evolutionary indicators and while there has been some work on characteristics of the androecium in the Myrtaceae, particularly in Eucalyptus (Bentham, 1867), in many genera there has been little or no detailed study.

Staminal structure in Syzygium is briefly discussed by Chantaranothai \& Parnell (1994a). They show that stamens of Syzygium are usually numerous (c. 40-50 per flower in S. balsameum to c. 1,200 in S. megacarpum), arranged in many whorls, the outermost of which is the longest and of anything from $1.5 \mathrm{~mm}$ (S. borneense) to 35 $\mathrm{mm}$ (S.jambos) long. Anthers are between $0.2 \mathrm{~mm}$ (S. borneense) and $1.8 \mathrm{~mm}$ ( $S$. samarangense) long, occasionally gland-dotted, dorsifixed, elliptic or ovate or, in large flowered species, linear-oblong. The connective usually bears a minute, apical gland whose function, if any, is equivocal.

Pickett \& Newsome (1997) indicated that pollen of the Myrtaceae is considered distinctive, being usually syncolpate or parasyncolpate. However, pollen grains of certain Sapotaceae do appear similar (Erdtman, 1952). Following Erdtman's (1952) early study of Haitian Eugenia chrootricha Urb. \& Ekman some noteworthy publications are a brief survey of the family (Pike, 1956), a few detailed studies of taxa likely to be important in fossil pollen studies (e.g., Huang, 1972; Chalson \& Martin, 1995; Pickett \& Newsome, 1997), one study of the pollen in the tribe Metrosiderinae (Gadek 
\& Martin, 1982), an unpublished one by Chantaranothai (1989) of Syzygium and two recent papers on pollen and anther morphology of the genus Verticordia (Ladd et al., 1999, 2000).

Pike (1956) recognised three pollen types in the Myrtaceae from the south-western Pacific region, separated from each other on the basis of their ectoaperture morphology, viz. longicolpate, syncolpate or parasyncolpate, and brevicolpate or brevissimicolpate. She suggested that the syncolpate and parasyncolpate groups were separate and that this character was taxonomically important. The reliability of these groups appeared to be confirmed by Patel et al. (1984). Grains are normally 3-colporate though Chantaranothai (1989) \& Huang (1972) found the inconsistent presence of 4-colporate grains in certain species. Recently, the study of the small but varied genus Verticordia by Ladd et al. $(1999,2000)$ has revealed a larger variety of pollen and anther types than was previously thought to occur in the family, and has related these to functionality of pollination.

This study focuses on the pollen morphology of Syzygium in Thailand. There are 84 species of Syzygium in Thailand (Chantaranothai \& Parnell, 1994a; Parnell \& Chantaranothai, 2000), of which the majority (57) have been surveyed for this paper, so forming a sample whose composition is comparable to that published by Parnell (1999). Many of the species surveyed also occur outside of Thailand; some (e.g., S.attenuatum, S. borneense, S. cinereum, S. claviflorum, S. cumini, S. grande, S. gratum, S.jambos, S. oblatum, S. polyanthum, S. syzygioides, and $S$. zeylanicum) are of widespread distribution in the Indo-Malesian region, others (e.g., S. glaucum, S. globiflorum, S. helferi, and S. hemisphericum) are of restricted distribution outside of Thailand, and a few are endemic to that country (e.g. S.aksornae). This paper is therefore of relevance to the study of the myrtaceous flora of a number of Malesian countries.

\section{MATERIAL AND METHODS}

The material used was obtained either from herbarium specimens lodged in the herbarium of Trinity College Dublin (TCD) or that of the Royal Forest Herbarium Bangkok (BKF), or, in the case of a single sample, from material lodged in Aarhus (AAU).

Pollen for scanning electron microscopy (SEM) was prepared following modification of the procedure outlined in Parnell (1991). Anthers were crushed in a c. 5 cc volume of $50 \%$ acetone, suspended using a whirli-mix and centrifuged (2,500 rpm for 8 minutes). The pellet (largely pollen) was then repeatedly dehydrated by re-suspension in increasing acetone concentrations (75-100\%), the penultimate re-suspended pellet was sieved $(90 \mu \mathrm{m})$ and the final pellet dropped onto a SEM stub and allowed to dry overnight in a dessicator. The stubs were gold-coated in a Polaron SC500 sputter coater for viewing in a Leica-Cambridge Stereoscan 360, Hitachi S4300 or Hitachi S3500N. The advantage of this method over conventional acetolysis is, principally, that it is very much quicker, and much less hazardous, and is less destructive of the 3-D structure of thin-walled pollen, while it cleans the pollen grains almost as well as acetolysis does. Generally, a minimum of three grains of any one collection (= taxon) were examined.

For transmission electron microscopy (TEM) air-dried anthers were fixed in glutaraldehyde $(3 \%)$ in $0.05 \mathrm{M}$ potassium phosphate buffer (1 hr); washed (6 times) in 


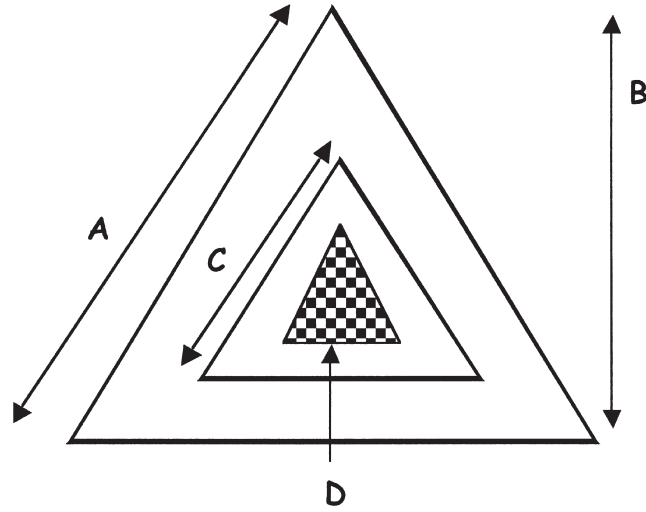

B

Fig. 1. Diagram illustrating measurements made on pollen grains of Syzygium. A = pollen grain size; $\mathrm{B}=$ pollen length in polar view; $\mathrm{C}=$ apocolpium size; $\mathrm{D}=$ apocolpial field (sometimes present).

$0.05 \mathrm{M}$ phosphate buffer ( $\mathrm{pH} \mathrm{7.2;} 1.5 \mathrm{hrs}$ total); postfixed in osmium tetroxide (2\%; $1 \mathrm{hr}$ ); post-stained with $2 \%$ aqueous uranyl acetate followed by Reynolds' lead citrate and embedded in Emix resin (Emscope) (Richardson et al., 1960). Sections were cut with a diamond knife and viewed on a Hitachi H7000TEM.

For pollen description I follow the terminology of Moore \& Webb (1978), Erdtman (1952), and Punt et al. (1994). A notable feature of pollen of Syzygium is the presence of an apocolpial field; that is, an area of the pollen grain enclosed by the polar anastomosis of the colpi and showing a distinct plug of sexine. However, the polar anastomosis of the colpi define an area usually larger than the apocolpial field which may or may not contain a plug of sexine. Following the suggestion of an anonymous referee the term apocolpium (sensu Erdtman, 1952) is used to describe this feature.

All pollen under SEM was photographed in polar view and measurements made of the length of the pollen grain's amb (along one edge) (A, Fig. 1), the maximal distance across the pollen grain (from one of the three tips of the grain in polar view to the midpoint of the amb opposite; B, Fig. 1) and of the length of the side of the apocolpium (C, Fig. 1).

Usually, the length of the pollen grain's amb (as measured along one edge; A, Fig. 1) is the largest size measurement that can be made on Syzygium pollen in polar view. However, where the amb is convex that is not the case and measurement B, Fig. 1, is very slightly larger. However, as the difference between measurements A and B is usually zero or very small measurement B appears superfluous. So, I follow another suggestion of the anonymous referee and henceforth use the phrase 'pollen size' as shorthand for the measurement of length of one side of the pollen grain's amb in polar view.

Both the pollen grain's polar face and the apocolpium form an equilateral triangular shape. The proportion of the area of the pollen grain in polar view occupied by the apocolpium was, therefore, calculated as the percentage difference between the two areas - each calculated, as for an equilateral triangle, as $=12 \sqrt{3} / 4$, where $1=$ the length of the side of the appropriate triangle (i.e. either measurement $\mathrm{A}$ or $\mathrm{C}$ above). In grains which are parasyncolpate the apocolpium is filled by an apocolpial field, which may occupy almost the entire area of the apocolpium or a small area; if the field appears absent the grain is termed syncolpate. The resulting data are presented in Table 1. 
To explore the relationship of the morphological variation between pollen morphology and gross morphological features the correlation between measurements presented in Parnell (1999) and data presented here were calculated. The resulting correlations are presented in Table 2. Finally, in order to try to see whether there was a difference in potential pollen production per stamen, stamen length was divided by 'pollen size' If pollen production per stamen is constant then there should be little variability in the ratio calculated.

\section{RESULTS}

Whilst processing of the anthers occurred, it was noticed that the gland of the apical connective did not appear to produce, or have produced, copious exudates in any species; though some appeared glossy.

\section{SEM}

Syzygium pollen is usually isopolar, radially symmetrical, suboblate (with a polar to equatorial diameter of 0.76-0.87 (Chantaranothai, 1989)), 3-(para)syncolporate [Chantaranothai (1989) noted that pollen of S. aromaticum may be 4-aperturate, and Huang (1972) noted a similar feature in S.javanicum; however, this feature has not been detected in this study] and weakly scabrate (Fig. 2a, b). The intercolpial concavities noted by Chantaranothai (1989) were not evident in the material sampled, probably due to the different preparation method used.

Table 1 details the measurements made and notes taken on SEM of pollen grains of Syzygium.

From Table 1 it is clear that pollen in Syzygium is small (sensu Walker \& Doyle, 1975); the average 'pollen size' over all species measured is c. $10.4 \mu \mathrm{m}$. Table 1 also
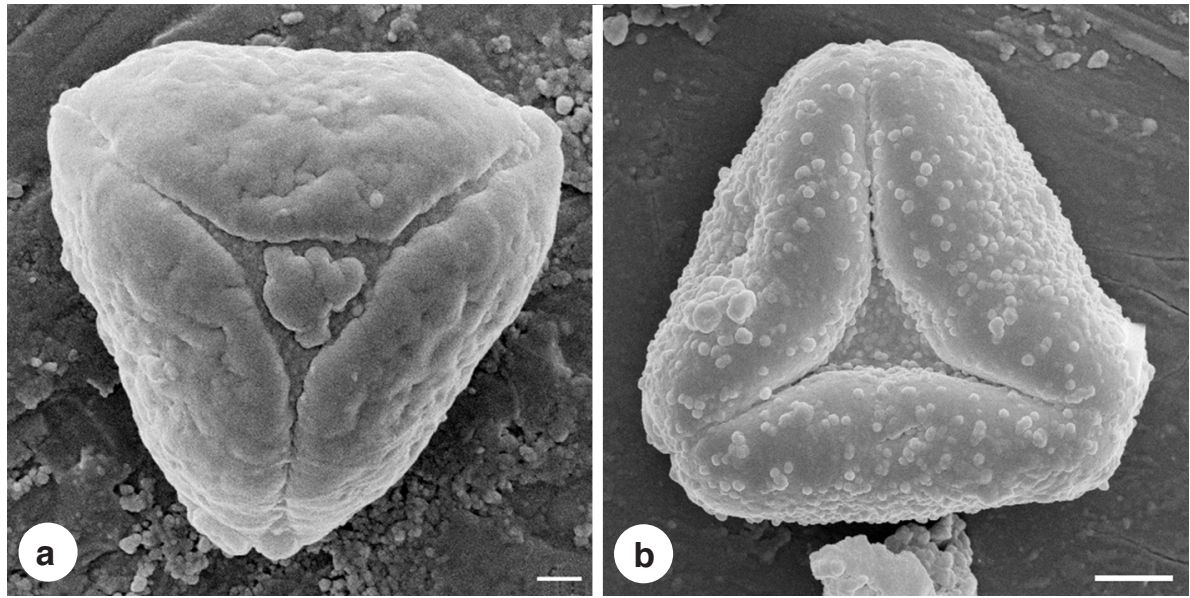

Fig. 2. SEM of a pollen grain. - a. Syzygium gratum in polar view, showing \pm triangular grain shape, \pm triangular apocolpium with an apocolpial field (plug of sexine) and low, weak scabrae on the surface. Scale bar $=1 \mu \mathrm{m}$. - b. S. formosum in polar view, showing \pm triangular grain shape, \pm triangular apocolpium and scabrate surface, possibly lacking an apocolpial field (plug of sexine) or with the apocolpial field sunken. Scale bar $=2 \mu \mathrm{m}$. 
Table 1. Pollen measurements of various Syzygium species, under SEM, and notes.

\begin{tabular}{|c|c|c|c|c|}
\hline Taxon & $\begin{array}{l}\text { 'Pollen size' in } \\
\text { polar view }(\mu \mathrm{m})\end{array}$ & $\begin{array}{r}\text { Apocolpial } \\
\text { edge }(\mu \mathrm{m})\end{array}$ & $\begin{array}{l}\text { Apocolpium } \\
\text { surface / area } \\
\text { polar face }(\%)\end{array}$ & Notes \\
\hline S. aksornae & 13.33 & 4.89 & 13.44 & \\
\hline S. albiflorum & 14.22 & 4.22 & 8.81 & \\
\hline S. anacardifolium & 13.33 & 4.89 & 13.44 & \\
\hline S. angkae & 13.33 & 5.33 & 16.00 & \\
\hline S. aqueum & 10.70 & 4.65 & 18.90 & \\
\hline S. aqueum & 11.00 & 4.57 & 17.27 & \\
\hline S. aromaticum & 13.28 & 5.34 & 16.21 & \\
\hline S. aromaticum & 15.88 & 8.25 & 26.99 & \\
\hline S. attenuatum & 11.72 & 5.17 & 19.46 & \\
\hline S. balsameum & 14.02 & 3.51 & 6.25 & \\
\hline S. borneense & 8.89 & 1.11 & 1.56 & \\
\hline S. campanulatum & 12.89 & 4.22 & 10.73 & Amb weakly convex \\
\hline S. cerasiforme & 9.14 & 2.07 & 5.13 & Apocolpial field present \\
\hline S. cinereum & 8.57 & 3.14 & 13.44 & \\
\hline S. cinereum & 10.00 & 3.30 & 10.92 & \\
\hline S. claviflorum & 11.38 & 5.00 & 19.31 & \\
\hline S. cumini & 11.29 & 3.71 & 10.83 & Apocolpial field present \\
\hline S. diospyrifolium & 9.82 & 4.39 & 19.93 & \\
\hline S. duthieaneum & 8.89 & 4.00 & 20.25 & \\
\hline S. dyerianum & 10.89 & 4.22 & 15.04 & Amb weakly convex \\
\hline S. fastigiatum & 9.14 & 3.79 & 17.23 & Apocolpial field present \\
\hline S. fastigiatum & 11.62 & 5.29 & 20.77 & \\
\hline S. fastigiatum & 10.89 & 4.44 & 16.66 & \\
\hline S.formosum & 12.00 & 3.56 & 8.78 & \\
\hline S. formosum & 12.45 & 4.15 & 11.11 & \\
\hline S. formosum & 14.15 & 4.72 & 11.11 & \\
\hline S. foxworthianum & 7.71 & 3.00 & 15.12 & \\
\hline S. fruticosum & 11.14 & 2.86 & 6.57 & $\begin{array}{l}\text { Apocolpium is not triangular; } \\
\text { apocolpial field present }\end{array}$ \\
\hline S.fuscescens & 11.14 & 4.71 & 17.90 & Apocolpial field present \\
\hline S. glaucum & 13.04 & 3.26 & 6.25 & \\
\hline S. glaucum & 12.22 & 4.44 & 13.22 & \\
\hline S. globiflorum & 18.76 & 7.42 & 15.65 & Large apocolpial field present \\
\hline S. grande & 10.71 & 3.14 & 8.60 & \\
\hline S. gratum & 11.04 & 3.75 & 11.53 & Apocolpial field present \\
\hline S. gratum & 9.75 & 3.13 & 10.27 & Apocolpial field present \\
\hline S. helferi & 11.11 & 4.00 & 12.96 & Apocolpial field present \\
\hline S. hemisphericum & 9.29 & 3.29 & 12.52 & Apocolpial field present \\
\hline S. hulletianum & 11.21 & 2.59 & 5.33 & Apocolpial field present \\
\hline S. ixoroides & 10.14 & 4.29 & 17.85 & Small apocolpial field present \\
\hline S. jambos & 11.74 & 7.17 & 37.35 & Amb weakly convex \\
\hline S.jambos & 17.14 & 9.71 & 32.11 & \\
\hline S. jasminifolium & 7.76 & 1.72 & 4.94 & Apocolpial field present \\
\hline S. leptostemon & 8.00 & 2.57 & 10.33 & Amb concave \\
\hline S. lineatum & 10.43 & 1.86 & 3.17 & \\
\hline S. maingayi & 9.50 & 6.25 & 43.28 & $\begin{array}{l}\text { Small apocolpial field present; } \\
\text { apocolpium is not triangular }\end{array}$ \\
\hline S. megacarpum & 18.37 & 4.42 & 5.78 & \\
\hline S. megacarpum & 12.00 & 2.89 & 5.80 & \\
\hline S. megacarpum & 15.81 & 4.65 & 8.65 & Apocolpium is not triangular \\
\hline S. mekongense & 13.04 & 1.96 & 2.25 & \\
\hline S. oblatum & 11.52 & 2.83 & 6.02 & Apocolpial field present \\
\hline S.pachyphyllum & 11.43 & 4.00 & 12.25 & \\
\hline S. papillosum & 12.09 & 4.88 & 16.31 & \\
\hline S. papillosum & 12.19 & 4.38 & 12.89 & \\
\hline
\end{tabular}


Table 1 (continued)

\begin{tabular}{|c|c|c|c|c|}
\hline Taxon & $\begin{array}{l}\text { 'Pollen size' in } \\
\text { polar view }(\mu \mathrm{m})\end{array}$ & $\begin{array}{l}\text { Apocolpial } \\
\text { edge }(\mu \mathrm{m})\end{array}$ & $\begin{array}{l}\text { Apocolpium } \\
\text { surface / area } \\
\text { polar face }(\%)\end{array}$ & Notes \\
\hline S. polyanthum & 9.03 & 2.64 & 8.54 & \\
\hline S. praecox & 14.13 & 6.52 & 21.30 & Apocolpial field present \\
\hline S.putii & 8.29 & 1.86 & 5.02 & \\
\hline S.pycnanthum & 11.14 & 5.00 & 20.13 & Apocolpial field present \\
\hline S.pyrifolium & 10.71 & 4.00 & 13.94 & $\begin{array}{l}\text { Small apocolpial field present; } \\
\text { amb concave }\end{array}$ \\
\hline S. refertum & 11.25 & 3.13 & 7.72 & \\
\hline S. rigens & 15.12 & 3.72 & 6.06 & \\
\hline S. ripicola & 9.86 & 1.74 & 3.11 & Apocolpium is not triangular \\
\hline S. ripicola & 12.56 & 3.02 & 5.80 & \\
\hline S. samarangense & 13.96 & 5.28 & 14.32 & \\
\hline S. samarangense & 15.12 & 6.05 & 16.00 & Small apocolpial field present \\
\hline S. samarangense & 13.48 & 3.26 & 5.85 & $\begin{array}{l}\text { Small apocolpial field present; } \\
\text { apocolpium is not triangular }\end{array}$ \\
\hline S. siamense & 17.21 & 7.44 & 18.70 & \\
\hline S. siamense & 12.93 & 4.14 & 10.24 & \\
\hline S. siamense & 12.63 & 2.81 & 4.94 & \\
\hline S. subrufum & 10.59 & 4.41 & 17.36 & \\
\hline S. syzygioides & 12.61 & 4.13 & 10.73 & \\
\hline S. tetragonum & 11.43 & 4.29 & 14.06 & \\
\hline S. thorelii & 11.47 & 2.94 & 6.57 & \\
\hline S. thorelii & 11.47 & 2.94 & 6.57 & \\
\hline S. thumra & 9.56 & 3.24 & 11.46 & \\
\hline S. winitii & 10.29 & 3.68 & 12.76 & Small apocolpial field present \\
\hline S. zeylanicum & 12.56 & 4.42 & 12.38 & Small apocolpial field present \\
\hline S. zimmermannii & 8.75 & 3.25 & 13.80 & \\
\hline Average & $10.41 \mu \mathrm{m}$ & $4.30 \mu \mathrm{m}$ & $16.70 \%$ & \\
\hline
\end{tabular}

shows that $S$. megacarpum had the largest pollen grains $(18.4 \mu \mathrm{m})$ and that these were more than twice the size of $S$. foxworthianum and S.jasminifolium which had the smallest $(7.7 \mu \mathrm{m})$. However, it is also clear that there is a degree of infraspecies variation in pollen measurements; for example, the largest pollen grains detected in $S$. siamense were $9 \%$ larger than the smallest grains $(13.5 \mu \mathrm{m})$ detected in the same species from a different collection and in S. siamense the difference between some collections was even larger at almost $27 \%$.

Table 1 shows that in S. leptostemon the pollen grain is not triangular in polar view as the amb is weakly concave and therefore the estimated area of the polar face of this species' pollen grain is, slightly, overestimated. In other species, e.g. one collection of $S$. jambos, the amb is slightly convex and the estimated area of the polar face of this collection of this species' pollen grain is, slightly, underestimated.

Table 1 also shows that there is considerable variation in the size of the apocolpium; the average apocolpium over all species measured has an edge of $4.3 \mu \mathrm{m}$. The smallest apocolpium is detected in $S$. borneense (with an edge of $1.1 \mu \mathrm{m}$ ) and the largest in S.jambos $(9.7 \mu \mathrm{m})$. The data also show that there are a few exceptions to the guideline that the apocolpium is triangular in outline. For example, in $S$. fruticosum the corners of the apocolpium are narrowed, tapering, and strongly elongated. In these species, noted 
Table 2. Significant correlations (Pearson product moment) between various measurements for various morphological characteristics from data used in Parnell (1999) and 'pollen size'. $*=p \leq 0.05$; $* *=\mathrm{p} \leq 0.01 ; \mathrm{df}=52$.

\begin{tabular}{lc}
\hline Character & $\begin{array}{c}\text { Correlation coefficient }(\mathrm{r}) \\
\text { of character with 'pollen size' }\end{array}$ \\
\hline Calyx-lobes length & $0.358^{* *}$ \\
Calyx-tube length & $0.466^{* *}$ \\
Petal length & $0.411^{* *}$ \\
Stamen length & $0.302^{*}$ \\
Style length & $0.295^{*}$ \\
\hline
\end{tabular}

in Table 1, the apocolpium is unavoidably somewhat underestimated by calculations of area based on an equilateral triangular shape due to the length of the tapering arms.

Table 1 also clearly shows a strong positive correlation between the length of the pollen amb and apocolpium $(\mathrm{r}=0.61 ; \mathrm{p} \leq 0.001 ; \mathrm{df}=75)$. In other words, larger pollen grains tend to have larger apocolpia.

Table 2 details the significant correlations between some of the data presented in Table 1 and various morphological characteristics and their measurements from Parnell (1999).

Table 2 shows that the 'pollen size' (and hence pollen area in polar view) is strongly and positively correlated with a number of morphological characteristics. In general, this means that the larger pollen grains occur in species with calyces with long tubes and lobes, and long petals, stamens, and styles. In other words, larger pollen grains tend to occur in species with larger flowers.

Calculation of the ratio of stamen length $(\mathrm{mm})$ to 'pollen size' $(\mu \mathrm{m})$ showed that S. anacardifolium, S. diospyrifolium, S. formosum, S. foxworthianum, S.jambos, S. megacarpum, $S$. pycnanthum, and $S$. siamense all showed ratios $\geq 1.5$ and that the smallest ratios were shown by $S$. balsameum and $S$. fruticosum $(<0.2)$; the modal and median ratio is 0.6 for all species. All species with a ratio $\geq 1.5$ belong to section Jambosa. However, not all members of section Jambosa possess this ratio - the ratio is 1.1 in $S$. aqueum, for example. A similar ratio can be calculated in respect of anther length / 'pollen size' and, as stamen length is strongly positively and linearly correlated with anther length $(\mathrm{r}=0.792 ; \mathrm{p} \leq 0.001 ; \mathrm{df}=79)$, the same argument applies. However, in this case $S$. subrufum also shows a high anther length / 'pollen size' ratio as it has exceptionally large anthers for the length of its stamens (1.4 and $12.2 \mathrm{~mm}$, respectively).

\section{TEM}

High quality TEM sections proved extraordinarily difficult to achieve. The satisfactory preparations presented herein took three years to obtain. The major difficulty was the hardness of the pollen grains causing infiltration and embedding difficulties: sectioning with a glass knife proved unsuccessful. TEM micrographs of S. claviflorum (Fig. 3) and S.formosum (Fig. 4) showed that the surface of the tectum is covered by pollenkit. Pollenkit is also visible in some preparations between the columellae (Fig. 4). The columellae are variable in diameter and spacing and are usually about $0.12 \times$ $0.10 \mu \mathrm{m}$. However, in some preparations no columellae are visible (Fig. 3). Scabrae, as 


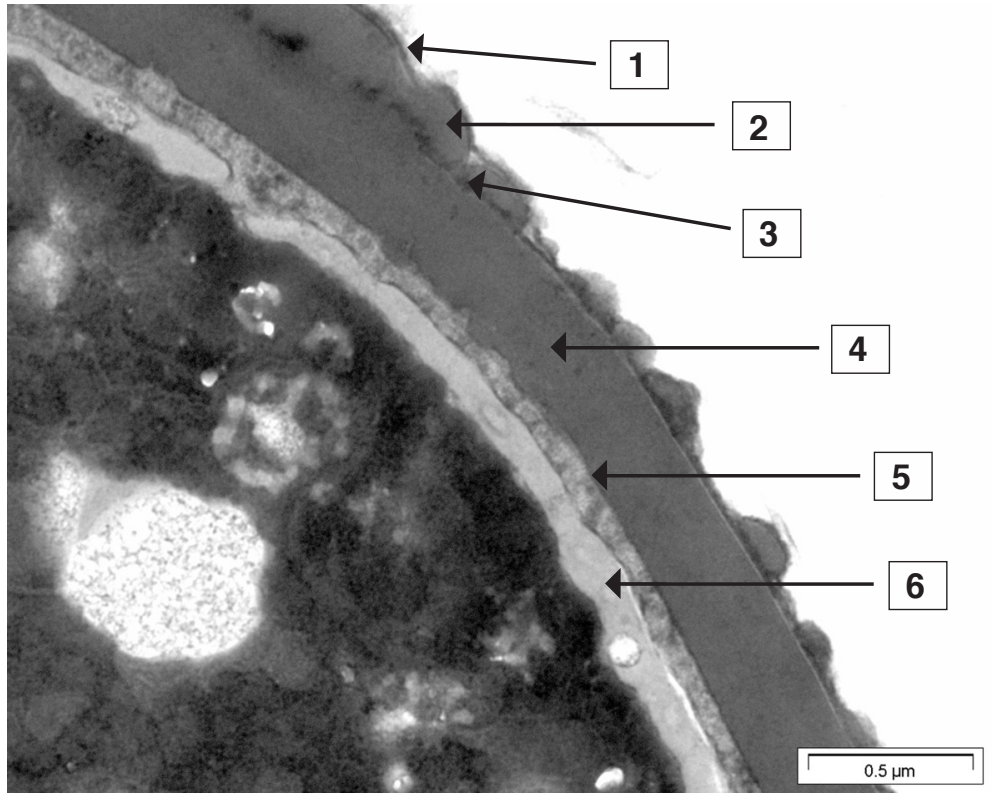

Fig. 3. TEM micrograph of pollen of $S$. claviflorum showing: $1=$ pollenkit; $2=$ tectum (possibly with supratectal processes); $3=$ infratectum with indistinct columellae ( 2 and 3 forming the sexine); $4=$ nexine (with no clear division into a footlayer and endexine); $5=$ intine; $6=$ cytoplasm?

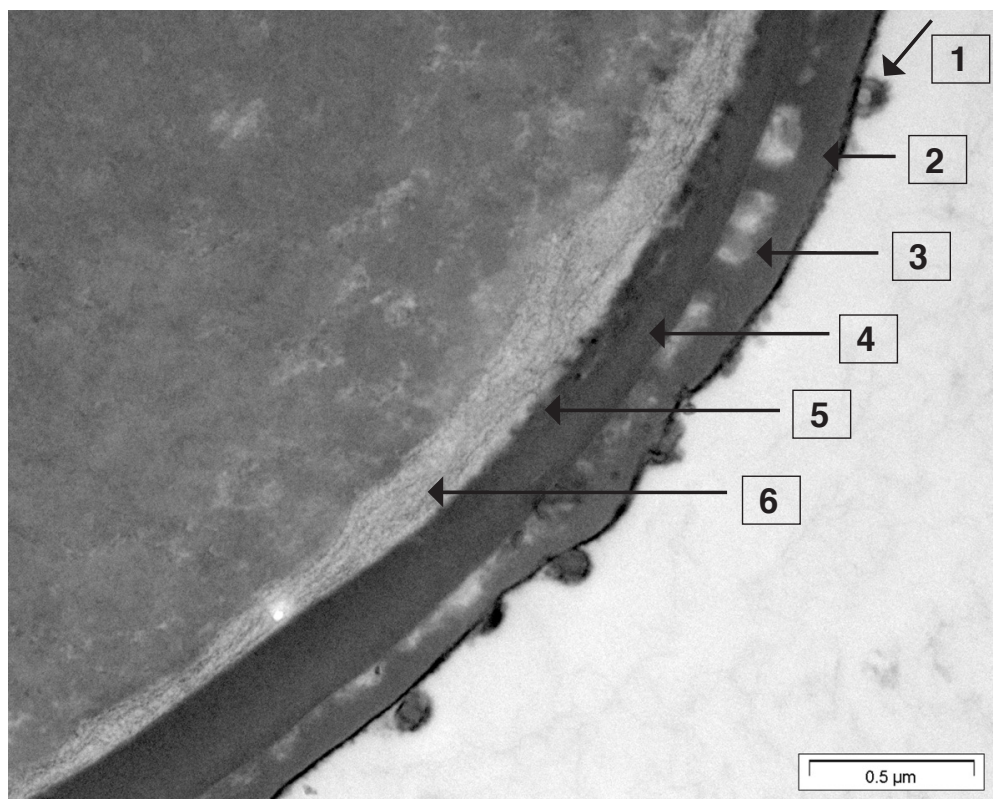

Fig. 4. TEM micrograph of $S$. formosum showing: $1=$ potential supratectal granule; $2=$ tectum; $3=$ collumellate infratectum; 4 . foot-layer?; $5=$ endexine? $(4$ and 5 forming the nexine); $6=$ intine. 


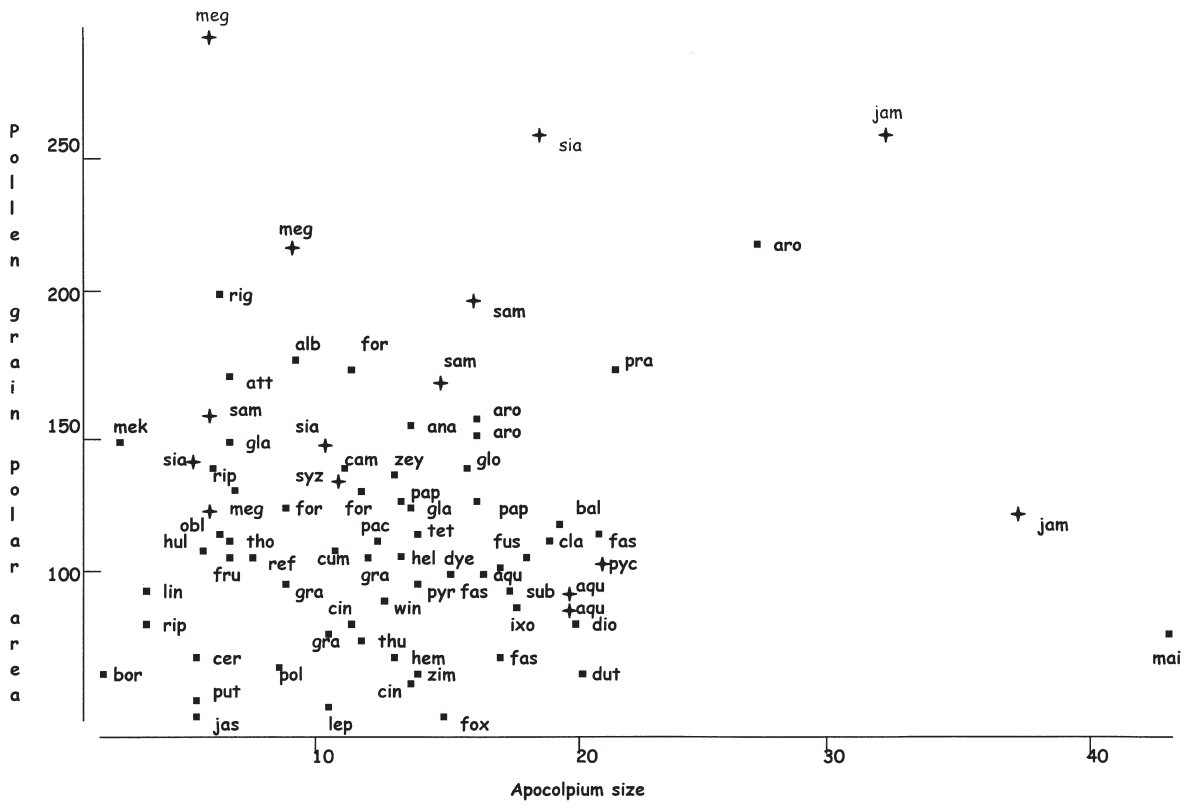

Fig. 6. Plot of pollen grain polar area $\left(\mu \mathrm{m}^{2}\right)$ against apocolpium size $\left(\mu \mathrm{m}^{2}\right)$ in Syzygium. $+=$ Jambosa section; = non-Jambosa section. Abbreviations used are as follows: aks = S. aksornae $; \mathbf{a l b}=$ $S$. albiflorum; $\mathbf{a n a}=S$. anacardifolium $;$ ang $=S$. angkae $; \mathbf{a q u}=S$. aqueum $;$ aro $=S$. aromaticum; $\mathbf{a t t}=S$. attenuatum $;$ bal $=S$. balsameum $;$ bor $=S$. borneense $;$ cam $=S$. campanulatum $;$ cer $=$ $S$. cerasiforme $; \boldsymbol{c i n}=S$. cinereum $;$ cla $=S$. claviflorum $;$ cum $=S$. cumini $;$ dio $=S$. diospyrifolium; dut $=S$. duthieaneum $;$ dye $=S$. dyerianum $;$ fas $=S$. fastigiatum $;$ for $=S$. formosum $;$ fox $=S$. fox worthianum $; \mathbf{f r u}=S$. fruticosum $;$ fus $=$ S. fuscescens $;$ gla $=$ S. glaucum $;$ glo $=$ S. globiflorum $;$ gra $=$ $S$. grande $;$ grat $=S$. gratum $;$ hel $=S$. helferi $;$ hem $=S$. hemisphericum $;$ hul $=S$. hulletianum $; \mathbf{i x o}=$ S. ixoroides $; \mathbf{j a m}=S$. jambos $; \mathbf{j a s}=S$. jasminifolium $; \mathbf{l e p}=$ S. leptostemon $;$ lin $=$ S. lineatum $; \mathbf{m a i}=$ S. maingayi $; \mathbf{m e g}=$ S. megacarpum $; \mathbf{m e k}=$ S. mekongense $; \mathbf{o b l}=$ S. oblatum $; \mathbf{p a c}=$ S. pachyphyllum; $\mathbf{p a p}=$ S. papillosum $; \mathbf{p o l}=$ S. polyanthum $; \mathbf{p r a}=$ S. praecox $; \mathbf{p u t}=$ S. putii $; \mathbf{p y c}=$ S. pycnanthum $; \mathbf{p y r}=$ $S$. pyrifolium $;$ ref $=S$. refertum $; \mathbf{r i g}=S$. rigens; rip $=S$. ripicola $; \mathbf{s a m}=S$. samarangense $;$ sia $=$ $S$. siamense $; \mathbf{s u b}=S$. subrufum $; \mathbf{s y z}=S$. syzygioides; tet $=S$. tetragonum $;$ tho $=S$. thorelii $;$ thu $=$ S. thumra $;$ win $=S$. winitii $;$ zey $=$ S. zeylanicum $; \mathbf{z i m}=$ S. zimmermannii .

seen under SEM, are sometimes visible (Fig. 3), depending on the angle of sectioning and protrude about $0.8-0.10 \mu \mathrm{m}$ above the surface of the tectum.

The foot layer is well developed and more or less of the same thickness as the tectum (Fig. 4).

The endexine is thin, c. $0.05 \mu \mathrm{m}$ thick and granular (Fig. 4). The intine is variable in thickness, between about $0.05-0.1 \mu \mathrm{m}$ thick, moderately electron transparent but has no identifiable cytoplasmic inclusions, though it sometimes appears fibrous (Fig. 4).

\section{DISCUSSION}

Given the very small differences in pollen grain size detected under SEM, the range of sizes found and the degree of variability detected in pollen size measurements, it 
appears that most species of Syzygium are not identifiable simply on the basis of pollen size. Species with exceptionally large or small grains, such as $S$. megacarpum and $S$. jasminifolium respectively, may appear distinctive but are only at the ends of what is a continuous distribution of range in size.

A plot of apocolpial size against pollen grain polar area offers the potential for differentiating the species (Fig. 5). Figure 5, a plot of pollen grain polar area against apocolpium, shows a scatter of species. It is also clear from this figure that there are no clear groupings of species but that the species placed in section Jambosa largely fall on the periphery of the species plotted; that is the pollen grains of the species in this section are generally relatively large in polar view with a relatively large apocolpium. Therefore, though it is not possible to allocate a species to section Jambosa on the basis of pollen size and relative apocolpium size alone, a plot of these two characteristics is indicative of group membership. However, remarkably, the calculated ratio of 'pollen size' to stamen length does pull out members of section Jambosa as only they possess ratios $\geq 1.5$. This, therefore, provides further evidence that section Jambosa is a recognisable entity.

Another feature of the apocolpium of some of the species surveyed is that it contains a plug of sexine, usually of triangular shape; these grains are parasyncolpate and the plug is referred to as the apocolpial field (Table 1; D, Fig. 1). Pike (1956) proposed that the presence or absence of an apocolpial field (whether the grain was parasyncolpate or syncolpate, respectively) was of taxonomic importance. As far as I can determine the presence of an apocolpial field is not linked to any known, or proposed, taxonomic grouping and occurs at random in Syzygium.

The pollen grains are not strongly ornamented (Fig. 2a, b), which is consistent with many other Myrtaceae taxa, and it is not possible to distinguish the species of Syzygium on the basis of surface ornamentation. It is due to the lack of variation in the pollen grains that the Myrtaceae is a difficult group to distinguish to a lower taxonomic level in fossil pollen studies (Pickett \& Newsome, 1997).

With few exceptions (Hopper, 1980; Chantaranothai \& Parnell, 1994a, b; and Nic Lughadha \& Proença, 1996) the pollination biology of most species of Syzygium remains unstudied. Within these limits, in summary, it is known that a number of different pollinator types visit flowers of Syzygium for either pollen or nectar or both. These visitors range from possums through bats to birds to species of ants, to butterflies to various species of bee (buzz pollination has not been reported); the latter are generally the most frequent visitors. The present paper does not demonstrate that there are any special adaptations evident in Syzygium pollen (e.g. co-production of oil/pollen mixture as occurs in some other Myrtaceae (Ladd et al., 1999, 2000) or lack of surface ornamentation) to facilitate a particular pollination strategy (Muller, 1980). The data available on breeding systems of Syzygium indicate that inbreeding (apomixis and self-pollination), and outbreeding or allogamous pollination occur in separate species (Chantaranothai \& Parnell, 1994b). However, these data are too sparse to allow for the relationships between breeding system and pollen morphology, if any, to be discussed. Further work, especially in terms of the analysis of the secretions produced by the apical connective gland and on breeding biology are vital if the evolution of Syzygium is to be understood. 
The positive correlation between flower size and pollen size found here for Syzygium parallels that found in the Dipterocarpaceae (Muller, 1979, 1980). The latter argues that the correlation reflects differences in nutrient supply, ultimately determined by selection for larger fruits. However, Ashton (1989) suggested that this correlation is more likely due to the fact that small-flowered Dipterocarpaceae are pollinated by thrips, whilst larger flowered species are also visited by larger insects. As staminal number varies considerably in the Dipterocarpoideae (from 5-110), Ashton (1979) suggests that this may give a better indication of pollen production than anther size. His argument may be applicable to Syzygium too, as considerable variation exists in staminal numbers in Syzygium (Chantaranothai \& Parnell, 1994a). In Syzygium the larger (and certainly the largest) staminal numbers are found in section Jambosa. This taken with the fact that species with large pollen grains have ratios of staminal length / 'pollen size' three times the median ratio for other species in the genus clearly requires further investigation and may be suggestive of a difference in breeding biology between section Jambosa and many other taxa in the genus.

By assuming pollen grains to be spherical and anthers to be simply cylindrical it is possible to calculate, based on the above data and those in Parnell (1999), the number of pollen grains per anther; such calculations are clearly approximations only. Nevertheless, they clearly indicate that species in section Jambosa produce at least 5 times $(\geq 500,000$ grains per anther) as many grains per anther as other species in the genus $(\mathrm{F}=17.1 ; \mathrm{df}=1.54 ; \mathrm{p} \leq 0.001)$. The most stamen-rich flowers in Syzygium occur in section Jambosa; therefore the pollen production per flower in this section is likely to significantly exceed that elsewhere. Further data on ovule numbers are essential if the breeding system of Syzygium is to be understood.

\section{ACKNOWLEDGEMENTS}

I acknowledge the help of Neal Leddy of the TCD Centre for Microscopy and Analysis in preparing the material for TEM and Dr. J. Macklin for preparing some of the pollen material for SEM. I am grateful to the Curator of BKF, Dr. Chamayarat, for permission to extract pollen from selected herbarium specimens and to an anonymous referee for helpful suggestions and interpretations of the TEM figures.

\section{REFERENCES}

Ashton, P.S. 1979. Some geographical trends in morphological variation in the Asian tropics and their possible significance. In: K. Larsen \& L.B. Holm-Neilsen (eds.), Tropical Botany: 35-48. Academic Press, London.

Ashton, P.S. 1989. Dipterocarp reproductive biology. In: H. Leith \& M.J.A. Werger (eds.), Ecosystems of the World 14B. Tropical rain forest ecosystems: 219-240. Elsevier, Oxford.

Bentham, G. 1867. Flora Australiensis. Vol. 3. Reeve \& Co., London.

Chalson, J.M. \& H.A. Martin. 1995. The pollen morphology of some co-occurring species of the family Myrtaceae from the Sydney region. Proc. Linn. Soc. N.S.W. 115: 163-191.

Chantaranothai, P. 1989. The taxonomy of Eugenia L. sensu lato (Myrtaceae) in Thailand. Unpublished $\mathrm{PhD}$ thesis. Trinity College Dublin.

Chantaranothai, P. \& J. Parnell. 1994a. A revision of Acmena, Cleistocalyx, Eugenia s.s. and Syzygium (Myrtaceae) in Thailand. Thai For. Bull. 21: 1-123.

Chantaranothai, P. \& J. Parnell. 1994b. The breeding biology of some Thai Syzygium species. Trop. Ecol. 35: 199-208. 
Erdtman G. 1952. Pollen morphology and plant taxonomy. Almqvist \& Wiksell, Stockholm.

Gadek, P.A. \& H.A. Martin. 1982. Exine ultrastructure of myrtaceous pollen. Aust. J. Bot. 30: $75-86$.

Hopper, S.D. 1980. Pollination of the rain-forest tree Syzygium itereyanum, Myrtaceae at Kurunda, Northern Queensland. Aust. J. Bot. 28: 223-237.

Huang, T-C. 1972. Pollen Flora of Taiwan. National Taiwan University, Botany Department Press.

Johnson, L.A.S. \& B.G. Briggs. 1981. Three old southern families - Myrtaceae, Proteaceae and Restionaceae. In: A. Keast (ed.), Ecological biogeography of Australia 1: 429-469. Junk, The Hague.

Johnson, L.A.S. \& B.G. Briggs. 1984. Myrtales and Myrtaceae - a phylogenetic analysis. Ann. Missouri Bot. Gard. 71: 700-756.

Johnson, L.A.S., B.G. Briggs, P.G. Wilson, B.P.M. Hyland \& J. Thompson. 1988. Myrtaceae. In: B.D. Morley \& H.R. Toelken (eds.), Flowering plants in Australia: 175-185. Rigby, Willoughby, Australia.

Kochummen, K.M. 1995. Eugenia. In: F.S.P. Ng (ed.), Tree Flora of Malaya 3: 172-247. Longman, London. Reprint of the 1978 edition.

Ladd, P.G., J. Parnell \& G. Thompson. 1999. Anther diversity and function in Verticordia DC. (Myrtaceae). Pl. Syst. Evol. 219: 79-97.

Ladd, P.G., Parnell, J. \& G. Thompson. 2000. The morphology of pollen and anthers in an unusual myrtaceous genus (Verticordia). In: M.M. Harley, C.M. Morton \& S. Blackmore (eds.), Pollen and spores: morphology and biology: 325-347. Royal Botanic Gardens, Kew.

Lemmens, R.H.M.J. 1995. Syzygium Gaertner. In: R.H.M.J. Lemmens, I. Soerianegara \& W.C. Wong (eds.), Plant Resources of South-East Asia (PROSEA) 5: 441-474. Timber trees: Minor commercial timbers. Backhuys Publishers, Leiden.

Mabberley, D.J. 1997. The Plant-book. 2nd ed. Cambridge University Press.

Moore, P.D. \& J.A. Webb. 1978. An illustrated guide to pollen analysis. Hodder \& Stoughton, London.

Muller, J. 1979. Pollen size in Dipterocarpaceae. Mem. Mus. Natl. Hist. Nat., Ser. B, 26: 35-40.

Muller, J. 1980. Form and function in angiosperm pollen. Ann. Missouri Bot. Gard. 66: 593-632.

Nic Lughadha, E. \& C. Proença. 1996. A survey of the reproductive biology of the Myrtoideae Myrtaceae. Ann. Missouri Bot. Gard. 83: 480-503.

Parnell, J. 1991. Pollen morphology of Jovibarba Opiz and Sempervivum L. (Crassulaceae). Kew Bull. 46: 733-738.

Parnell, J. 1999. Numerical analysis of Thai members of the Eugenia-Syzygium group (Myrtaceae). Blumea 44: 351-379.

Parnell, J. \& P. Chantaranothai. 2000. Myrtaceae.In: T. Santisuk, K. Larsen, I. Neilsen, K. Chayamarit, I. Hedge, J. Dransfield, B. Hansen, C. Phengklai, J. Vidal, K. Iwatsuki, J. Parnell \& M. Roos (eds.), Flora of Thailand 8: 778-914. Forest Herbarium, Royal Forest Department, Bangkok.

Patel, V.C., J.J. Skvarla \& P.H. Raven. 1984. Pollen characteristics in relation to the delimitation of the Myrtales. Ann. Missouri Bot. Gard. 71: 858-969.

Pickett, E.J. \& J.C. Newsome. 1997. Eucalyptus (Myrtaceae) pollen and its potential role in investigations of Holocene environments in southwestern Australia. Rev. Palaeobot. Palynol. 98: 187-205.

Pike, K.M. 1956. Pollen morphology of Myrtaceae from the south-west Pacific area. Aust. J. Bot. 4: $13-53$.

Punt, W., S. Blackmore, S. Nilsson \& A. le Thomas. 1994. Glossary of pollen and spore terminology. Laboratory Palaeobotany and Palynology Contributions Series 1. LPP Foundation, Utrecht.

Richardson, K.C., L. Jarret \& E.H. Finke. 1960. Embedding in epoxy resin for ultrathin sectioning in electron microscopy. Stain Tech. 35: 313-323.

Schmid, R. 1980. Comparative anatomy and morphology of Psiloxylon and Heteropyxis, and the subfamilial and tribal classification of Myrtaceae. Taxon 29: 559-595.

Walker, J.W. \& J.A. Doyle. 1975. The bases of angiosperm phylogeny: palynology. Ann. Missouri Bot. Gard. 62: 664-723. 
Appendix. Species sampled, specimens used, and specimen source.

\begin{tabular}{|c|c|c|}
\hline Species & Collector & Herbarium \\
\hline S. aksornae Chantar. \& J. Parn. & Kerr 12238 & TCD \\
\hline S. albiflorum (Duthie \& Kurz) Bahadur \& R.C. Gaur & Kerr 1084 & TCD \\
\hline S. anacardiifolium (Craib) Chantar. \& J. Parn. & Kerr 12081 & TCD \\
\hline S. angkae (Craib) Chantar. \& J. Parn. & Van Beusekom \& Phengklai 366 & BKF \\
\hline S. aqueum (Burm.f.) Alston & Santisuk s.n. & \\
\hline S. aromaticum (L.) Merr. \& L.M. Perry & Cult. & TCD \\
\hline S. attenuatum (Miq.) Merr. \& L.M. Perry & Smitinand 291 & BKF \\
\hline S. balsameum (Wight) Walp. & Kerr 2761 & TCD \\
\hline S. borneense (Miq.) Miq. & Kerr 12061 & TCD \\
\hline S. campanulatum Korth. & Kerr 15964 & TCD \\
\hline S. cerasiforme (Blume) Merr. \& L.M. Perry & Kerr 12034 & TCD \\
\hline S. cinereum (Kurz) Chantar. \& J. Parn. & Kerr 4978 & TCD \\
\hline S. claviflorum (Roxb.) A.M. Cowan \& Cowan & $\begin{array}{l}\text { Chantaranothai, Chamayarat, } \\
\text { Middleton, Parnell \& Simpson 1198* }\end{array}$ & * TCD \\
\hline S. cumini (L.) Skeels & Kerr 12525 & TCD \\
\hline S. duthieanum (King) Masam. & Chan 6711 & \\
\hline S. dyerianum (King) Chantar. \& J. Parn & Kerr 7475 & TCD \\
\hline S. fastigiatum (Blume) Merr. \& L.M. Perry & Kerr 18155 & TCD \\
\hline S. formosum (Wall.) Masam. & Chantaranothai 1764; Kerr 8899 & TCD \\
\hline S. foxworthianum (Ridl.) Merr. \& L.M. Perry & Kerr 7701 & TCD \\
\hline S. fruticosum DC. & Kerr 39 & TCD \\
\hline S. fuscescens (Craib) Chantar. \& J. Parn & Kerr 16574 & TCD \\
\hline S. glaucum (King) Chantar. \& J. Parn. & Kerr 5166 & TCD \\
\hline S. globiflorum (Craib) Chantar. \& J. Parn. & Garrett 559 & TCD \\
\hline S. grande (Wight) Walp. & Kerr 14000 & TCD \\
\hline S. gratum (Wight) S.N. Mitra & $\begin{array}{l}\text { Chantaranothai, Parnell, Middleton \& } \\
\text { Simpson 849; Kerr } 17306\end{array}$ & \& TCD \\
\hline S. helferi (Duthie) Chantar. \& J. Parn. & Kerr 11386, 18313 & TCD \\
\hline S. hemisphericum (Wight) Alston & Smitinand 10351 & BKF \\
\hline S. hulletianum (King) Chantar. \& J. Parn. & & \\
\hline S. ixoroides Chantar. \& J. Parn. & Phumsomsaeng 257 & BKF \\
\hline S. jambos (L.) Alston in Trimen & Florence 11033 & TCD \\
\hline S. jasminifolium (Ridl.) Chantar. \& J. Parn. & $\begin{array}{l}\text { Sangkhachand, Phumsomsaeng \& } \\
\text { Nimanong } 1073\end{array}$ & $\mathrm{BKF}$ \\
\hline S. leptostemon (Korth.) Merr. \& L.M. Perry & $\begin{array}{l}\text { Koyama, Phengklai, Niyondham \& } \\
\text { O'Connor } 15246\end{array}$ & BKF \\
\hline S. lineatum (DC.) Merr. \& L.M. Perry & Kerr 9283 & TCD \\
\hline S. maingayi Chantar. \& J. Parn. & Kerr 15550 & TCD \\
\hline S. megacarpum (Craib) Rathakr. \& N.C. Nair & Chantaranothai s.n.; Kerr 1230 & TCD \\
\hline S. mekongense (Gagnep.) Merr. \& L.M. Perry & $\begin{array}{l}\text { Chantaranothai, Parnell, Simpson \& } \\
\text { Sridit 90/225 }\end{array}$ & TCD \\
\hline S. oblatum (Roxb.) Wall. ex A.M. Cowan \& Cowan & Collins 1806 & TCD \\
\hline S. pachyphyllum (Kurz) Merr. \& L.M. Perry & Kerr 18563 & TCD \\
\hline S. papillosum (Duthie) Merr. \& L.M. Perry & Nyomdham 1644 & BKF \\
\hline S. polyanthum (Wight) Walp. & Kerr 1497 & TCD \\
\hline S. praecox (Roxb.) Rathakr. \& N.C. Nair & Kerr 17007 & TCD \\
\hline S. putii Chantar. \& J. Parn. & Kerr 18602 & TCD \\
\hline S. pycnanthum Merr. \& L.M. Perry & $\begin{array}{l}\text { Shikizu 27318; } \\
\text { King's Collector } 5855 \text { (Perak) }\end{array}$ & BKF; TCD \\
\hline S. pyrifolium (Blume) DC. & King's Collector 10984 (Perak) & TCD \\
\hline S. refertum (Craib) Chantar. \& J. Parn. & Kerr 10472 & TCD \\
\hline S. ridleyi (King) Chantar. \& J. Parn. & Corner 34942 & BKF \\
\hline S. rigens (Craib) Chantar. \& J. Parn. & Kerr 12045 & TCD \\
\hline
\end{tabular}


Appendix 1 (continued)

\begin{tabular}{lll}
\hline \multicolumn{1}{c}{ Species } & Collector & Herbarium \\
\hline S. ripicola (Craib) Merr. \& L.M. Perry & Kerr 8638 & TCD \\
S. samarangense (Blume) Merr. \& L.M. Perry & Chantaranothai s.n.; Kerr 4059 & TCD \\
S. siamense (Craib) Chantar. \& J. Parn. & Chantaranothai 1765; Kerr 12565A; & TCD; TCD; \\
& Nyomdham 2913 & BKF \\
S. subrufum (King) Masam. & Kerr 4915 & TCD \\
S. syzygioides (Miq.) Merr. \& L.M. Perry & Kerr 1363 & TCD \\
S. tetragonum (Wight) Walp. & Kerr 8654 & TCD \\
S. thorelii (Gagnep.) Merr. \& L.M. Perry & Kerr 8379 & TCD \\
S. thumra (Roxb.) Merr. \& L.M. Perry & Kerr 8784 & TCD \\
S. winitii (Craib) Merr. \& L.M. Perry & Kerr 5762 & TCD \\
S. zeylanicum (L.) DC. & Kerr 15684 & TCD \\
S. zimmermannii (Warb.) Merr. \& L.M. Perry & Kerr 5747; K. Larsen, S.S. Larsen, & TCD; AAU \\
& Renner, Niyomdham, Ueachirakan \& & \\
& Sirirugsa 42903 & \\
* = used for TEM. & & \\
\hline
\end{tabular}

